\title{
The Assessment of The Quality, Efficacy and Safety of The Investigational Medicinal Product in The Absence of An Approved Registration Dossier
}

\author{
Voronina Ekaterina Vladimirovna ${ }^{1,2 *}$ \\ ${ }^{1}$ Researcher, Federal Institution "State Research Institute of Genetics and Selection of Industrial Microorganisms of the National Research Center" \\ Kurchatov Institute", Russia \\ ${ }^{2}$ Head of eukaryotic cultivation unit, LLC Pharmapark, Russia
}

Submission: July 30, 2019; Published: August 14, 2019

*Corresponding author: Voronina Ekaterina Vladimirovna, Researcher, Federal Institution "State Research Institute of Genetics and Selection of Industrial Microorganisms of the National Research Center" Kurchatov Institute", Moscow, Russia

Head of eukaryotic cultivation unit, LLC Pharmapark, Moscow, Russia

Keywords: batch release for clinical trials, authorized person, pharmaceutical development

\section{Opinion}

Today the pharmaceutical industry is one of the highly regulated fields with many rules and regulations which are quite volatile and are updated at least every decade [1-8]. Practical guidelines and recommendations are published by regulatory authorities and manufacturers even more often. As a result, things that were state-of-the art yesterday may not be appropriate tomorrow, especially in the rapidly changing area of biopharmaceutical development.

The procedure for the production and release of each batch of medicinal product is typically based on requirements of Good Manufacturing Practice (GMP). They are adequate for the developed and registered drug but difficult to follow for investigational medicinal product intended for clinical trials. Production for clinical trials differs from production of registered products due to uncertainty of specifications for raw materials, primary packaging materials, intermediate products, bulk and finished products, limited experience in the production of the investigational drug, smaller scales, lack of full validation of manufacturing process and analytical methods, incomplete knowledge about the product stability, etc. These data are obtained in a process of technology development, scale up, pilot production - the processes performed at the same time with early clinical trials. Forcing manufacturers to obtain these data before going to clinic will postpone registration of the new drugs and reduce the quality of healthcare system.
The specifications, technological instructions and dossiers for batches of investigational drugs may be limited in scope and change in the process of their development, and therefore the authorized person releasing the batches is faced with the prob lem of effective and rapid assessment of all changes. He needs to be absolutely sure that participants are not placed at risk arising from unsatisfactory manufacture or control of clinical batches. Some security actions have to be performed in any case, for example, viral safety evaluations, viral removal, sterile filtration, complete release testing.

To reduce the risk of inconsistency between batches, every manufacturer should develop its own systematic approach where every component of the quality information will contribute to the overall assessment, take a case-by-case judgment call on extent of quality data requirements at time of application or as a post-approval commitment, analyze literature data for the similar products. Moreover, he should compare all drug substance and drug product batch results, look for variability and inconsistencies for registration and define critical points. And authorized person needs to comply with a complex and demanding set of legal, ethical and regulatory requirements, contravention of which may lead to criminal proceedings.

These approaches will eliminate possible risks for patients, as well as ensure that the results of clinical studies are not affect- 
ed by insufficient safety, quality or efficacy of the drug, resulting from inadequate production and incomplete control.

\section{References}

1. Guideline on the requirements for the chemical and pharmaceutical quality documentation concerning investigational medicinal products in clinical trials (EMA/CHMP/QWP/545525/2017).

2. Guideline on the requirements for the chemical and pharmaceutica quality documentation concerning investigational medicinal products in clinical trials - Revision1 (EMA/CHMP/QWP/545525/2017).

3. Overview of comments received on 'Guideline on the requirements for the chemical and pharmaceutical quality documentation concerning investigational medicinal products in clinical trials' (EMA/CHMP/ QWP/834816/2015)

This work is licensed under Creative

Commons Attribution 4.0 License

DOI: 10.19080/CTBEB.2019.19.556016
4. Draft guideline on the requirements to the chemical and pharmaceutical quality documentation concerning investigational medicinal products in clinical trials (EMA/CHMP/QWP/834816/2015).

5. Draft concept paper on the need for revision of the guideline on the requirements to the chemical and pharmaceutical quality documentation concerning investigational medicinal products in clinical trials (EMA/CHMP/QWP/126334/2015).

6. Guideline on the requirements to the chemical and pharmaceutical quality documentation concerning investigational medicinal products in clinical trials (CHMP/QWP/185401/2004).

7. Ludwig Huber (2015) COMPLIANCE FOR BIOPHARMACEUTICAL LABORATORIES.

8. (2009) Guidance for Industry Q8(R2) Pharmaceutical Development.

Your next submission with Juniper Publishers will reach you the below assets

- Quality Editorial service

- Swift Peer Review

- Reprints availability

- E-prints Service

- Manuscript Podcast for convenient understanding

- Global attainment for your research

- Manuscript accessibility in different formats

( Pdf, E-pub, Full Text, Audio)

- Unceasing customer service

Track the below URL for one-step submission https://juniperpublishers.com/online-submission.php 